Article

\title{
Analysis of the Relationship between Support Institutions and Industrial Districts in Spain: A Regional Approach
}

\author{
Enrique Claver-Cortés, Bartolomé Marco-Lajara, Pedro Seva-Larrosa * $\mathbb{D}$, Lorena Ruiz-Fernández \\ and Eduardo Sánchez-García \\ Department of Business Organization, University of Alicante, E-03080 Alicante, Spain; \\ enrique.claver@ua.es (E.C.-C.); bartolome.marco@ua.es (B.M.-L.); lorena.fernandez@ua.es (L.R.-F.); \\ eduardo.sanchez@ua.es (E.S.-G.) \\ * Correspondence: pedro.seva@ua.es
}

Received: 30 November 2018; Accepted: 9 January 2019; Published: 25 January 2019

check for updates

\begin{abstract}
One of the constituent elements of the industrial district is the existence of local and regional institutions which offer information and support services to the firms based in the district. These institutions, as has been shown in the literature on industrial districts, in addition to representing an important component of social capital, can play a key role in improving the joint operation of the companies in the district. The aim of this paper is, consequently, to analyze the food industry districts and the institutions which support this industry nationally. With that aim in mind, the analysis is undertaken from a regional perspective that allows us to assess, on the one hand, the degree of proximity between districts and institutions and, on the other hand, the role played by the latter as knowledge generators. The results obtained show that, in general, the support institutions tend to be located in the vicinity of the industrial districts specialized in the aforementioned sector. It likewise becomes clear that the training offer aimed at meeting the training needs of the industry is greater in these specialized environments than in others where this production model does not prevail. Such results confirm the importance of institutions in business agglomerations shaped as industrial districts.
\end{abstract}

Keywords: industrial districts; clusters; specialization; institutional thickness; knowledge; training offer; food industry

\section{Introduction}

The existence of local and regional institutions, which offer information and support services to the firms based in the district and support services to the firms based in the district which additionally represent a significant component of social capital (Parra-Requena et al. 2013). The geographical proximity between firms and individuals, as well as that between firms and local institutions, improves efficiency: It facilitates the dissemination of ideas and technical innovations as well as various forms of collaboration between firms and the political context; it improves social cohesion; it encourages a feeling of collective awareness; and it makes operations between firms easier and faster. Thus, in the district, where competitiveness and cooperation relationships coexist (Parra-Requena et al. 2008) it is the firms, the institutions, and the individuals that can use an efficient collaboration to exchange competitively valuable knowledge and to stimulate learning economies (Asheim et al. 2011). Currently, geographical proximity seems to be a powerful factor of legitimacy of institutions that through local policies places institutional geography as a privileged mode of economic interactions (Torre and Rallet 2005). 
Given the importance corresponding to institutions within the district theory, as well as the role that they play with regard to business competitiveness in such environments, we set ourselves a twofold objective in this paper. Firstly, to analyze the relationship in the nationwide spatial distribution between industrial districts and the industry support institutions in which the district is specialized. And secondly, to examine the role of institutions as generators of knowledge for the district firms.

The empirical research is oriented toward verifying the hypotheses posed that revolve around the Spanish food industry (foodstuffs and beverages). In Spain, the food and beverage sector stands out as the first industrial branch and comprises a total of 31,342 enterprises ${ }^{1}(17.4 \%$ of the whole manufacturing industry). According to the latest Encuesta Industrial de Empresas [Industrial Firm Survey] carried out by the INE [(Spain's) National Statistics Institute], it accounts for $20.5 \%$ of net product sales, $18.3 \%$ of employed persons, $18.0 \%$ of gross investment in material assets, and $15.5 \%$ of the Spanish industrial sector's added value. Furthermore, the value of the Spanish food industry production in 2017 exceeded 100 billion euros for the first time, especially thanks to the growth of its exports, which increased by 9\% compared to the previous year (Informe Económico 2017).

Our study contributes to the literature in two ways: (i) It analyzes the spatial relationship between the food industrial districts nationwide and the institutions associated with that sector. The importance of institutions to improve the joint operation of district firms (Parra-Requena et al. 2013), among other organizational issues, is well-known. However, an aspect not addressed so far has to do with how firms are distributed across the territory, and more precisely, about whether they are located near industrial districts in Spain. To cover this gap in the literature, a total of 443 institutions in the field of the food industry at the national level have been analyzed. Specifically, 58 technological centers and research institutes, 51 universities, 173 vocational training centers, 136 entrepreneurs' associations and 25 interprofessional organizations; (ii) it permits to know whether those environments with a higher degree of specialization in the food industry offer a larger training offer, aimed at meeting the industry's training demand. Furthermore, we have developed a map which allows us to know the spatial distribution of industrial food districts and institutions (universities and vocational training centers) that offer specialized training to the industry.

To that end, our paper is structured as follows. After this short introduction, Section 2 offers a review of the literature which deals with the role played by institutions in the industrial district context. Likewise, we describe the institutions included in the empirical analysis in a general way. Section 3 explains the methodological aspects of our paper, and Section 4 presents the main results obtained from the analysis. Finally, we end the study with a summary of our most important findings and conclusions (Section 5).

\section{Literature Review and Hypotheses}

\subsection{Institutions and Industrial Districts}

The literature on industrial districts identifies different types of agents which form the structure of relationships inside the district, amongst which these stand out: (1) A set of firms belonging to the main industry; (2) input and service providing firms; (3) distributing and customer firms; (4) firms of related sectors offering products which are complementary to the main industry; and (5) institutions which supply information and technical support. Within this group of agents, the institutions play a key role in district development. Becattini (2002) himself identifies the formation of institutions, which mediate between the need for specialization and versatility, as one of the processes from which district nature derives.

1 According to the data supplied by INE's Directorio Central de Empresas [Central Directory of Enterprises], as of 1 January 2018. 
These institutions may have either a public or a private nature and are usually identified with research centers, universities, training centers, entrepreneurs' associations, financial entities, etc. They may likewise be both formal and informal institutions (Becattini 2002). The former includes entrepreneurs' associations, trade unions, technical schools, technological centers, universities and purchase or sale consortia, to quote but a few; whereas lobbies or other types of social institutions, amongst others, stand out as examples of the latter. The basic goal sought by these institutions is to offer support to the firms belonging to the localized industry in such diverse aspects as specialized training, education, information, research, and technical support (Porter and Ketels 2009). In that sense, they cover important functions relating to cooperation, advice, training and mediation between the different firms, and between them and other bodies, both inside and outside the district. From this perspective, the geographic framework of economic interactions is largely conditioned by the role of institutions (Torre and Rallet 2005).

Several definitions of proximity offered by the literature on economics, business organization or economic geography include institutions as a relevant notion, among others, such as space, interindividual relations, etc. In the field of economics, some authors (Kirat and Lung 1999) refer to three types of proximity (institutional, organizational, and geographical), while others, such as Torre and Rallet (2005), distinguish two types of proximity (geographical and organized).

Based on this distinction, the authors propose an analysis of the main models of geographical organization of activities through the articulation of both types of proximity. Among the main organizational models, the industrial districts are characterized by the existence of both types of proximity. In this model, organizational proximity, defined as the intensity of customer-supplier relationships, the exchange of technical knowledge or the existence of an "industrial atmosphere", is based on the co-location of actors within a defined area. Within organizational proximity, it highlights the role of institutions and other organizations in mitigating the negative effects of geographical proximity, for example, to resolve conflicts or introduce cooperation or negotiation processes with ad hoc mechanisms.

Several reasons could be adduced to recognize in general the strategic value of institutions in regional development and particularly the proper functioning of industrial districts. On one side, they perform the basic - albeit not less important-function of supplying information and providing technical support to the firms located in the district. And on the other side, they foster the quantity and quality of relationships between agents, thus acting as «versatile integrators» (Becattini 2002). However, they not only encourage greater trust but also foster entrepreneurship and make the incorporation of firms into the district easier (Amin and Thrift 1995). They equally serve to monitor the strategic process, which ultimately explains the existence of a collective strategy (Camisón and Molina-Morales 1998) that improves the joint operation of district firms (Parra-Requena et al. 2013).

Being aware of the role played by institutions in regional and local development (both the national government and the regional as well as the local ones), local authorities sometimes try to promote the creation of public and/or private institutional organizations with the aim of boosting the development of regional productive sectors. ${ }^{2}$ The studies about economically successful regions suggest that their success partly depends on institutional thickness. The concept of «institutional thickness» refers to an interconnected and integrated network of organizations and institutions which give support to regional and/or local enterprises (Amin and Thrift 1995), highlighting, not only the presence of such institutions, but also the interaction synergies, collective representation, and a common purpose of the agents involved (Keeble et al. 1999). Thus, the search for synergies among local actors has become the alpha and omega of most policies of local development (Torre and Rallet 2005). These institutions participate, amongst other aspects, in the exchange of knowledge and experience aimed at promoting

2 Initiatives also exist at a supranational level to promote the competitiveness of regions, e.g., the «new European regional development policy», which places the emphasis on knowledge, innovation, and social capital to achieve this aim. 
cooperative activity (Boucher et al. 2003). Similarly, some regions encourage interrelationships between universities, scientific laboratories, and productive fabrics to improve the processes of innovation, commercialization, management and training in enterprises (Belzunegui Eraso et al. 2017).

Below, some of the institutions mentioned above are summarily described and will be analyzed later in the empirical part. Specifically, six types of institutions are described: Technological centers; research institutes; universities; vocational training centers; entrepreneurs' associations; and interprofessional organizations.

Technological Centers. According to the Spanish Federation of Technological Centers (FEDIT for its initials in Spanish), these are non-profit private research bodies which have available the material and human resources needed to generate technological knowledge and facilitate its business exploitation. In that respect, their success is measured according to the competitive improvement of enterprises and to their contribution to the economic development achieved in their context. Technological centers have proven to be an effective tool in the accomplishment of technological improvements and innovations which allow firms to increase their productivity levels and their growth capacity within an increasingly global and strongly competitive business context. Thus, under various legal forms, technological centers act as strategic partners of firms, and constitute an agile and effective link to support R\&D\&I, mainly addressed to the productive sector and particularly to SMEs. However, they also collaborate with public administrations in the implementation of activities related to technological innovation.

Research Institutes. They perform an important role of support for innovation and make it easier for enterprises to access valuable information about the latest technologies and the R\&D\&I being carried out in fields which are relevant for the sector. Likewise, they offer specialized advice in various fields of interest (technology, training, legislation, subsidies, as well as state, regional, provincial or local programs of interest for enterprises belonging to this sector, amongst others). The same as technological centers, research institutes also act as integrating agents through the promotion of collaboration between SMEs.

Universities. Universities have a twofold role. On the one hand, they train skilled workers through their training programs (degrees, master's degrees, PhD programs, etc.), thus providing firms with suitably trained and qualified staff (Razak and Saad 2007). On the other hand, they generate scientific knowledge by means of research and see to it that the outcome of such research activities can reach the different economic sectors as much as possible. This double role positions universities as central players in regional innovation, driving local economic growth via the supply of human capital and the new knowledge generated in their main tasks, as are teaching and research. Furthermore, both universities and research institutes place at firms' disposal the use of several technologies, which they can access through the acquisition of their corresponding patents (Drejer and Jørgensen 2005; Maggioni et al. 2007). This is what some authors (Charles et al. 1995; Oakey 1995) have termed as the commoditization of knowledge through intellectual property rights, technological transfer, scientific parks, and spin-off companies.

Vocational Training Centers. Vocational training is the educational level that prepares future workers to carry out a professional activity and enables them for a qualified performance of the different professions, taking a clearly practical orientation. Therefore, the main purpose of vocational training is to train students to develop activities in a specific professional field. Vocational training studies in Spain are structured into 26 professional families and, inside them, into Basic Vocational Training titles, Intermediate Degree titles and Higher Degree titles. Within the group of vocational training centers, an outstanding role is performed by those recognized with the qualification as National Reference Centers (CRN for their initials in Spanish). ${ }^{3}$

3 These centers are institutions at the service of vocational training systems to favor a more competitive training and respond to the changes operated in the qualification demand of productive sectors. Their goal thus consists in planning and implementing actions of an innovative, experimental, and formative nature in the area of vocational training for 
Entrepreneurs' Associations. They are non-profit organizations (Dalziel 2006) which usually bring together a large part of the entrepreneurs belonging to a specific sector and region, thus achieving a certain degree of cohesion between them, insofar as their membership in the association is based on the common needs of its members. These associations deliver a wide variety of services to their members, both directly and indirectly, and additionally act on most occasions as representatives of those members, in defense of their interests. Therefore, their raison d'être is to act for the benefit of their members, which, given the collective nature of their actions, may positively impact both on business results and on the degree of cohesion and trust of their members. According to Bullinger et al. (2004) interfirm cooperation, as well as the cooperation between SMEs and other external agents-regardless of whether they are economic or not-has a favorable effect on knowledge dissemination and innovation development.

Interprofessional Organizations. These institutions comprise organizations which are representative of production, transformation, and where applicable, the commercialization and distribution of a specific sector or product. Their aims may include an improvement in the quality of the products and processes eventually carried out from the production stage to their arrival at the end consumer. Also promoting R\&D programs meant to boost innovation processes across the different sectors, together with the promotion and dissemination of knowledge between them.

Given the importance of institutions within the district theory, as well as the role that they play in relation to the business competitiveness of such environments, it becomes necessary to adopt a territorial perspective for the analysis of the relationship that exists between the industrial districts of a specific sector and the institutions which support it. For that purpose, the concepts of «institutional thickness» and «regional specialization» served as the basis to develop a $2 \times 2$ contingency matrix which distinguishes between the degree of specialization achieved by a region and its institutional thickness (Figure 1). The combination of these two variables and the extent to which they take place result in four possible alternatives: (1) Region specialized in a specific industry and with a high institutional thickness in that industry; (2) region specialized in a specific industry, but with a low institutional thickness; (3) region with a low degree of specialization in a specific industry, but with a high institutional thickness; (4) region with a low degree of specialization in a specific industry and a low institutional thickness.

\begin{tabular}{|c|c|c|c|}
\hline & & \multicolumn{2}{|c|}{ Institutional thickness } \\
\hline & & High & Low \\
\hline \multirow{2}{*}{ 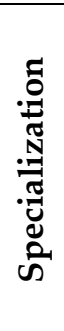 } & 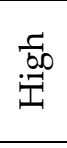 & $\begin{array}{l}\text { Region specialized in a specific industry } \\
\text { and with a high institutional thickness in } \\
\text { that industry }\end{array}$ & $\begin{array}{c}\text { Region specialized in a specific industry, } \\
\text { but with a low institutional thickness in } \\
\text { that industry }\end{array}$ \\
\hline & 3. & $\begin{array}{l}\text { Region with a low degree of specialization } \\
\text { in a specific industry, but with a high } \\
\text { institutional thickness in that industry }\end{array}$ & $\begin{array}{c}\text { Region with a low degree of } \\
\text { specialization in a specific industry and } \\
\text { a low institutional thickness in that } \\
\text { industry }\end{array}$ \\
\hline
\end{tabular}

Figure 1. Specialization-institutional thickness.

If the firms belonging to an industrial district benefit from the presence of institutions in the geographical context of the district, in the aspects already mentioned above, one could expect the existence of a relationship between the location of industrial districts and the institutions which give support to their firms. In order to settle this issue, we set ourselves the objective of examining the

employment, so that they can serve as a referent for the whole National System of Qualifications and Vocational Training to develop vocational training. 
relationship between the food industry institutions and the food industrial districts around the country. The following hypothesis is thus posed:

Hypothesis $\mathbf{1}$ (H1). The productive specialization of a region is positively related to the presence of institutions that support the industry.

\subsection{Knowledge and Industrial Districts}

Another aspect that is worth analyzing, in addition to the presence of supporting institutions around the district, is their role as generators of knowledge for firms. This is so because, apart from the knowledge generated by competitors and suppliers, an important external source of knowledge for the enterprises based in an industrial district/cluster can be found in the jointly located institutions (McCann and Folta 2011). In that sense, universities, technological centers, research institutes, etc., are institutions which generate knowledge-sometimes generic and, on other occasions, specific.

Intangible resources have acquired great importance during the last few decades because of their strategic value (Barney 1991; Grant 1991), to the extent of becoming highly relevant factors when it comes to creating value for firms (Lev and Daum 2004). Amongst these intangible resources, knowledge, which stems from the interaction between individuals and organizations, stands out. It is often argued that the greater the distance between agents, the more difficult it will be to transfer knowledge, especially tacit and/or contextual knowledge (Gallaud and Torre 2004; Gertler 2003). In that sense, some authors (Feldman and Massard 2002) highlight the transfer of knowledge or information to explain co-localization. The district stages the successive concentration of highly specialized techniques and knowledge which can be accessed by the group of enterprises located therein (Marco-Lajara et al. 2018) and contextual knowledge which is acquired at a district level (Rodríguez-Cohard and Parras 2011). Likewise, the existence of a knowledge base shared by the firms has direct implications on the ease in the use of knowledge shared with external partners (Knudsen 2007). In short, the knowledge generated in the district is a specific intangible resource or one with an idiosyncratic - as well as contextual—value in the sector, since it has more value in the place where it was generated and acquired than anywhere else.

On the whole, firms may acquire knowledge from internal and external sources (Díaz-Díaz and Pérez 2014; Dyer and Singh 1998; Lane and Lubatkin 1998). Internal sources have to do with the actions that the firm itself analyzes to improve its knowledge base. A distinction can be drawn within external sources between the knowledge coming from other industry firms (rivals or not) and coded knowledge, training appears as an important component of the latter. Nevertheless, due to the difficulties that companies find to internally generate all the knowledge they require, it becomes crucial for them to be located in those places where they can take advantage of the knowledge derived from relationships with other agents and institutions based in their immediate environment. In the industrial district context, we could distinguish the «industrial atmosphere» described by Marshall (1920), which essentially refers to tacit knowledge, from the training acquired by district workers (explicit knowledge). Our attention in this paper will focus on external knowledge sources, more precisely, on training offered by universities and vocational training centers, through which workers, and therefore the enterprises located in industrial districts, acquire knowledge specific to the industry.

As highlighted above, knowledge is one of the main sources of competitive advantage that a firm can have at present (Marco-Lajara et al. 2018). Consequently, one can expect the firms located in a delimited geographical area with a high productive specialization, as it happens in industrial districts, to demand workers with knowledge (training) specific to the sector. From the workers' point of view, they will request more industry-specific training with the aim of achieving a better adaptation to the labor market demands. In other words, the training demand will be greater in these areas with a higher productive specialization compared to others where such a specialization does not exist. In response 
to the foregoing, institutions (universities, training centers, institutes, etc.) will offer a higher number of places oriented to meeting the training needs of the industrial sector specific to the region.

Seeking to test the above, we decided to analyze the training offer in the context of the food industry and its relationship with the food industrial districts at a national level. This leads us to the next three hypotheses:

Hypothesis $2 \mathbf{~ ( H 2 ) . ~ T h e ~ p r o d u c t i v e ~ s p e c i a l i z a t i o n ~ o f ~ a ~ r e g i o n ~ i s ~ p o s i t i v e l y ~ r e l a t e d ~ t o ~ t h e ~ t r a i n i n g ~ o f f e r ~ a i m e d ~ a t ~}$ the industry in which the region is specialized.

Hypothesis 2a (H2a). The productive specialization of a region is positively related to the university training offer aimed at the industry in which the region is specialized.

Hypothesis $\mathbf{2 b} \mathbf{( H 2 b ) . ~ T h e ~ p r o d u c t i v e ~ s p e c i a l i z a t i o n ~ o f ~ a ~ r e g i o n ~ i s ~ p o s i t i v e l y ~ r e l a t e d ~ t o ~ t h e ~ v o c a t i o n a l ~ t r a i n i n g ~}$ offer aimed at the industry in which the region is specialized.

The following section provides an explanation of the methodology utilized for the analysis, and aims to be as specific as possible, in view of the importance that the aspects related to the reproducibility and replicability of research outcomes have been acquiring lately (Peng 2015). In other words, we want to ensure that, if a researcher attempts to replicate or reproduce a research work using the same data and techniques, similar results will be obtained-which in turn helps to increase research quality and rigor.

\section{Methodology}

A total of 443 institutions belonging to the food industry nationwide were analyzed for examining the spatial relationship existing between industrial districts and institutions, where we plan to verify $\mathrm{H} 1$ (the productive specialization of a region is positively related to the presence of institutions that support the industry). More specifically, 58 technological centers and research institutes, 51 universities, 173 vocational training centers, 136 entrepreneurs' associations, and 25 interprofessional organizations of the food and agriculture sector. ${ }^{4}$ Starting from the previous information, an institutional index was created to measure the presence of institutions supporting the food industry in each province. The location of their centers was taken into account considering the province as the territorial unit of analysis (NUTS-3). ${ }^{5}$

In addition, industrial food districts have been identified based on Local Labor Systems (LLSs). In Spain LLSs have been previously identified by Boix and Galletto (2006), whose work serves as the basis for our study. In the aforementioned work, 806 LLSs were identified in the different branches of economic activity at the national level. Consequently, our task was focused to verify which of the LLSs identified by these authors continue to be valid, in our case, limited to the food industry. For this purpose, data related to employment and population are used for the year 2018. This led us to identify 437 municipalities throughout the national territory belonging to 37 LLSs that meet the conditions to be considered industrial districts and that we have called Food Industrial Districts (FIDs). Based on the results obtained, two subsamples have been distinguished: one composed of those provinces in which there are industrial food districts and the other in those in which there are none.

4 For the purposes of Law 38/1994, an Interprofessional Food and Agriculture Organization is understood as one formed by organizations which are representative of production, of transformation and, where applicable, of the food and agriculture commercialization and distribution, of a sector or product included within the food and agriculture system. Only one Interprofessional Food and Agriculture Organization per sector or product can be recognized, even though the regulatory Law envisages a number of exceptions for products with specific markets or differentiated destinations and for those entitled to the use of figures protecting differentiated quality (Ministry of Agriculture, Fishing and Food).

5 However, in the work the terms "province" and "region" are used interchangeably, since this has a national scope (Spain). 
As for the analysis of the training offer in the food industry, where they try to contrast the hypotheses related to the availability of knowledge through training ( $\mathrm{H} 2, \mathrm{H} 2 \mathrm{a}$ and $\mathrm{H} 2 \mathrm{~b})$, we took into consideration the knowledge generated by universities and vocational training centers. A total of 371 training programs (134 from universities and 237 from vocational training centers) were examined for that purpose. More precisely, attention was paid, on the one hand, to the degrees, master's degrees and $\mathrm{PhD}$ programs available in the food industry context in the 52 Spanish provinces ${ }^{6}$ and, on the other hand, to vocational training programs at their different levels (Basic VT; Intermediate VT; and Higher VT).

This information served as the basis to create three indices which measure training in the food industry context by provinces: University training index; vocational training index; and overall training index. The same as in the preceding case, two sub-samples arose from obtaining the training indices for each province (namely, provinces with and without Food Industrial Districts).

As other authors have previously done (Camisón and Molina-Morales 1998; López-Estornell et al. 2015), the empirical verification was implemented with a bivariate analysis performed through a difference of means with independent samples. Student's $t$-test was applied to the two aforementioned groups with that aim. Therefore, if there are no significant differences between the two groups, one could infer that the location of industrial districts in a province does not affect the variable in question, and vice versa. Prior to implementing the test, we applied Levene's Test to confirm the homoskedasticity hypothesis. Should the variable not fulfill this requirement, Welch's statistic was calculated because of its robustness in the absence of variance equality. All data were treated using the statistical software SPSS@ in its version 24.

\section{Data Collection and Variable Measurement}

The data utilized in the analysis mainly stem from secondary sources, several of which helped us to assess the presence of institutions. Amongst those secondary sources, these stand out: The Universia database, ${ }^{7}$ the Ministry of Agriculture, Fishing and Food; the Spanish Federation of Technological Centers (FEDIT for its initials in Spanish); the Spanish Federation of Food and Beverage Industries (FIAB for its initials in Spanish); and the National Registry of Associations, amongst others.

As regards the training offer in the food industry context, a distinction can be drawn between data referring to university training and those linked to vocational training. In order to assess university training, we initially resorted to the Universia database, which allowed us to develop our own database about university training in Spain's food industry. The information obtained during this first stage was subsequently compared with the information published by each university on its website. Instead, our assessment of vocational training relied on data supplied by the Ministry of Education and Vocational Training. ${ }^{8}$

The variable specialization (SPEC) served to check whether there are food industrial districts in a province or not. This dummy variable takes the value 1 if the province has one or more food industrial districts within its administrative boundaries, and the value 0 otherwise. This way of measuring the existence of a unit of analysis in a specific territory has been widely used in the literature about industrial districts or clusters (Bell 2005; Belso-Martínez et al. 2011; Parra-Requena et al. 2013). The unit of analysis is usually the firm, however, and therefore these works try to draw a distinction between the firms which belong to an industrial district and those which do not.

The variable institutional thickness (INST-TH) assesses the presence of institutions in a specific territory (province). This variable was measured through an index calculated in accordance with the number of institutions which support the food industry in each province, relativized by the

650 provinces plus 2 autonomous cities (Ceuta and Melilla).

7 Universia is the reference university network for Latin America which brings together more than 1341 universities and has been sponsored by Banco Santander since its creation.

8 Data that it supplies through the web page «todofp.es», managed by the Ministry of Education and Vocational Training. 
number of firms belonging to this sector. The institutions considered to calculate this index included: Technological centers; research institutes; universities; vocational training centers; ${ }^{9}$ entrepreneurs' associations; and interprofessional organizations.

To measure the knowledge resources in an area, some previous works (Marco-Lajara et al. 2017; Marco-Lajara et al. 2018) have considered the presence of the centers educational and qualifications offered. In a similar way to these authors, in this work we have considered the presence of the centers and the degrees, but we have also considered the number of places offered in each of the degrees. The three variables used to measure the knowledge resources evaluated are described below.

The variable university training (UNITR) measures the training offer in the food industry context provided by universities in a specific territory (province). This variable was measured through an index which takes into account the total number of places offered for each training program (degree, master's degree, and $\mathrm{PhD}$ ) and province, relativized by the number of inhabitants in each province.

The variable vocational training (VOCTR) measures the training offer in the food industry context provided by the vocational training centers in a specific territory (province). Similar to the previous case, this variable was measured using an index which considers the total number of places offered at each one of the vocational training levels (basic, intermediate, and higher) ${ }^{10}$ and province, relativized by the number of inhabitants in each province.

Finally, the variable overall training (OVETR) assesses the training offer in the food industry context supplied by universities and vocational training centers in a specific territory (province) and results from the sum of the two preceding indices.

\section{Results and Discussion}

Table 1 shows the list of food industrial districts and institutions by province. ' + ' appears in the second column in those provinces where one or more food industrial districts have been identified. ' + ' likewise appears in the following columns referred to technological centers and research institutes, universities, vocational training centers, entrepreneurs' associations, and interprofessional organizations.

Table 1. Food industrial districts and institutions by provinces, 2018.

\begin{tabular}{|c|c|c|c|c|c|c|}
\hline Provinces & $\begin{array}{c}\text { Food } \\
\text { Industrial } \\
\text { Districts } \\
\text { (FIDs) }\end{array}$ & $\begin{array}{l}\text { Technological } \\
\text { Centers and } \\
\text { Research } \\
\text { Institutes of the } \\
\text { Food Industry }\end{array}$ & $\begin{array}{l}\text { Universities with } \\
\text { a Training Offer } \\
\text { of the Food } \\
\text { Industry }\end{array}$ & $\begin{array}{c}\text { Vocational } \\
\text { Training Centers } \\
\text { with a Training } \\
\text { Offer of the Food } \\
\text { Industry }\end{array}$ & $\begin{array}{c}\text { Entrepreneurs' } \\
\text { Associations of } \\
\text { the Food } \\
\text { Industry }\end{array}$ & $\begin{array}{c}\text { Recognized } \\
\text { Interprofessional } \\
\text { Food and } \\
\text { Agriculture } \\
\text { Organizations }\end{array}$ \\
\hline Álava & & & + & + & & \\
\hline Albacete & & & + & + & & \\
\hline Asturias & & & + & + & + & \\
\hline Ávila & & & + & & & \\
\hline Badajoz & + & + & + & + & + & + \\
\hline Barcelona & + & + & + & + & + & + \\
\hline Burgos & & & + & + & & \\
\hline Cáceres & & & + & & + & \\
\hline
\end{tabular}

9 In the case of universities and vocational training centers, we only took into account those whose training offer contains at least one training program related to the food industry, in any of its modalities and training levels.

10 According to the classification utilized by the Ministry of Education and Vocational Training and depending on the level to which it refers, the teaching programs included in the analysis are: Basic Vocational Training (teaching about bakery and confectionery activities, and food industries); Intermediate Vocational Training (teaching about olive oils and wines, preparation of food products, and bakery, cake-making and confectionery); Higher Vocational Training (teaching about processes and quality in the food industry, and wine-growing and producing). 
Table 1. Cont.

\begin{tabular}{|c|c|c|c|c|c|c|}
\hline Provinces & $\begin{array}{c}\text { Food } \\
\text { Industrial } \\
\text { Districts } \\
\text { (FIDs) }\end{array}$ & $\begin{array}{l}\text { Technological } \\
\text { Centers and } \\
\text { Research } \\
\text { Institutes of the } \\
\text { Food Industry }\end{array}$ & $\begin{array}{l}\text { Universities with } \\
\text { a Training Offer } \\
\text { of the Food } \\
\text { Industry }\end{array}$ & $\begin{array}{c}\text { Vocational } \\
\text { Training Centers } \\
\text { with a Training } \\
\text { Offer of the Food } \\
\text { Industry }\end{array}$ & $\begin{array}{c}\text { Entrepreneurs' } \\
\text { Associations of } \\
\text { the Food } \\
\text { Industry }\end{array}$ & $\begin{array}{c}\text { Recognized } \\
\text { Interprofessional } \\
\text { Food and } \\
\text { Agriculture } \\
\text { Organizations }\end{array}$ \\
\hline Ciudad Real & + & & + & + & + & + \\
\hline Córdoba & + & + & + & + & & \\
\hline Coruña, A & & & + & + & + & \\
\hline Cuenca & + & & & & + & \\
\hline Gipuzkoa & & + & + & + & & + \\
\hline Girona & + & & + & + & + & \\
\hline Granada & & + & + & + & + & \\
\hline Guadalajara & & & & & + & \\
\hline Huelva & + & + & & + & & \\
\hline Huesca & & & & + & + & \\
\hline I. Baleares & & & + & + & & \\
\hline Jaén & + & + & + & + & + & \\
\hline La Rioja & + & + & + & + & + & \\
\hline Las Palmas & & & & + & & \\
\hline León & & & + & + & & \\
\hline Lleida & + & & + & + & & + \\
\hline Lugo & & & & + & + & \\
\hline Madrid & + & + & + & + & + & + \\
\hline Málaga & & + & & + & + & \\
\hline Murcia & + & + & + & + & + & + \\
\hline Navarra & + & + & + & + & + & \\
\hline Ourense & & & & + & & \\
\hline Palencia & & + & & + & + & \\
\hline Pontevedra & + & + & + & + & + & \\
\hline S. Tenerife & & & + & + & & \\
\hline Salamanca & + & + & + & + & + & \\
\hline Segovia & & + & & & & \\
\hline Sevilla & + & + & + & + & + & + \\
\hline Soria & + & & & & & \\
\hline Tarragona & & & + & + & & \\
\hline Teruel & & & & + & + & \\
\hline Toledo & + & & & + & + & \\
\hline Valencia & + & + & + & + & + & + \\
\hline Valladolid & & + & + & + & + & \\
\hline Vizcaya & & + & + & + & & \\
\hline Zamora & & & & + & + & \\
\hline Zaragoza & + & + & + & + & + & \\
\hline Ceuta & & & & + & & \\
\hline Melilla & & & & & & \\
\hline
\end{tabular}

By means of a contingency matrix, Table 2 summarizes the results drawn from the proximity analysis. More precisely, we are referring to the process of comparison between those Spanish provinces in which food industrial districts were identified and the regions where the institutions belonging to that industry are located. The rows show the degree of specialization in the different regions (high specialization when there are food industrial districts and low when such districts do not exist), whereas the columns reflect the institutional thickness of provinces (high institutional thickness if there are at least six institutions supporting the food industry and low otherwise). ${ }^{11}$ The values in the right-hand column and in the bottom row represent the marginal frequencies of the variables institutional thickness and specialization.

The first results show that there are food industrial districts in 21 out of 52 Spanish provinces. In the light of the foregoing and considering that a total of 37 food industrial districts have been identified in Spain, this means that productive specialization not only exists inside industrial districts but also by regions. In other words, while provinces such as La Rioja or Murcia have four industrial

11 A criterion which was established in our paper to consider that a province has institutions which support the food industry. Or expressed differently, in order to have a high institutional thickness, a province must count on at least six supporting institutions. The minimum standards required to consider that district-supporting institutions exist in a province thus become stricter. 
districts each within their administrative boundaries, this production model is less representative and even non-existent sometimes in other regions.

Table 2. Specialization-institutional thickness by provinces.

\begin{tabular}{lcccc}
\hline & & \multicolumn{2}{c}{ Institutional Thickness } \\
\hline \multirow{3}{*}{ Specialization } & $\begin{array}{c}\text { Provinces with } \\
\text { Institutions }\end{array}$ & $\begin{array}{c}\text { Provinces without } \\
\text { Institutions }\end{array}$ & \\
\cline { 2 - 5 } & FIDs & 19 & 2 & 21 \\
& Provinces without & $90.48 \%$ & $9.52 \%$ & 31 \\
\hline FIDs & 8 & 23 & $74.19 \%$ & \\
\hline
\end{tabular}

As for the districts-institutions relationship, $90.48 \%$ of the provinces where food industrial districts exist also have at least six institutions supporting that industry, whereas $9.52 \%$ of the provinces with districts are not home to such institutions. Instead, $25.81 \%$ of the provinces in which there are not food industrial districts have institutions which support this industry, while $74.19 \%$ of the provinces without districts are not home to such institutions either (little presence of the food industry in these regions).

Table 3 reveals the number of cases in each group-provinces with and without food industrial district - the mean, the standard deviation, and the variation coefficient for both groups. The statistical analysis performed through the Student's $t$-test shows that differences in means exist between both samples and that they are statistically significant $(p \leq 0.028)$. Therefore, hypothesis 1 can be deemed as confirmed. Thus, it is possible to state that the food industry support institutions are located near the geographical context of food industrial districts.

Table 3. Comparison between provinces with/without districts and food industry institutions.

\begin{tabular}{ccc}
\hline & \multicolumn{2}{c}{ Institutional Thickness } \\
\hline & Provinces with FIDs & Provinces without FIDs \\
\hline No. of cases & 21 & 31 \\
Mean & $1.455^{* *}$ & 0.864 \\
Standard deviation (SD) & 1.129 & 0.755 \\
Variation Coefficient (VC) & 0.776 & 0.874 \\
\hline & ${ }^{*} p \leq 0.1 ;{ }^{* *} p \leq 0.05 ;{ }^{* * *} p \leq 0.01$.
\end{tabular}

The variation coefficient (VC) suggests that the institutional thickness in provinces where food industrial districts exist is more homogeneous than in provinces which lack that production model in that industry. This might be due to the fact that provinces with FIDs generally have a high number of institutions which give support to the industry, whereas this only seems to be the case on some occasions in provinces without FIDs which in turn implies differences in the degree of homogeneity between the two samples used.

To this must be added that vocational training centers are more homogeneously distributed (with presence in practically all provinces) than the other institutions analyzed, for the purpose of providing a diversified training offer in the different regions, even if the latter do not show a significant specialization. Nevertheless, it is worth highlighting that the vocational training centers qualified as National Reference Centers (CRN for their initials in Spanish) of Food Industries ${ }^{12}$ are located close to

12 More specifically, there are three centers with that qualification in Spain: the CRN of vegetal preserves in Molina de Segura (Murcia); the CRN of beverages, oils and fats in Ciudad Real (Castile-La Mancha); and the CRN of meat, dairy and bakery industries in Salamanca (Castile and León). 
the areas regarded as FIDs. Instead, other institutions such as technological centers or entrepreneurs' associations show higher heterogeneity in their locations, being situated near districts with the aim of improving the competitive factors of the SMEs located therein (Comeche Martínez et al. 2006). In sum, there is one institutional base common to the whole national territory and another specific one in the case of certain territories (coinciding with those where the activity revolves around a specific production model, the industrial district).

The results obtained in connection with the training offer can be found below. First, it shows the spatial distribution of industrial food districts and centers, both universities and vocational training centers, which offer some training program oriented to the specific training of that industry (Figure 2). Second, we can also note the total number of places offered in each of the provinces, distinguishing between the two sources of knowledge analyzed (university education and vocational training). Finally, the results of the statistical analysis and its implications are presented.

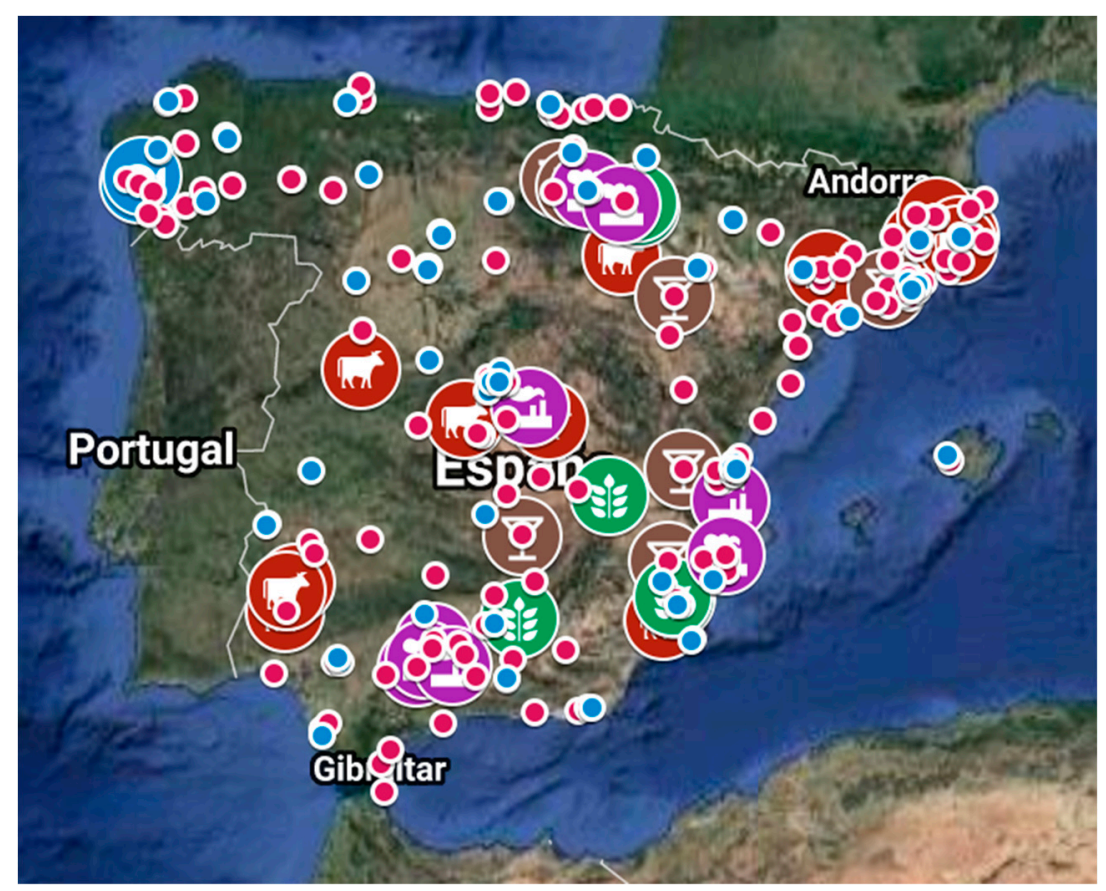

Figure 2. Food industrial districts and centers (universities and vocational training) that offer training programs for the food industry.

The food industry (food and beverages) represents one of the fields with the largest number of industrial districts in the Iberian country. According to Boix and Trullén (2011) there are 37 industrial food and beverage districts, just behind the case of products for the home (62 districts) and textiles and clothing (46 districts). In addition, according to these authors, the occupation within the industrial food districts (51,000 employees) represents a not insignificant percentage $(12.7 \%)$ of the occupation of the food industry in Spain.

Figure 2 shows the industrial food districts (represented by the sign), the university training centers (blue dots/spots) that offer training related to the food industry and the vocational training centers (red dots) that similarly offer this type deformation. Likewise, each industrial food district is in turn identified with its specialization: Beverages (7 districts); meat products (13 districts); fruits and vegetables (6 districts); fish (2 districts); other food products (5 districts); several (4 districts). At the aggregate territorial level, most of the districts are concentrated in three axes. The central axis crosses the peninsula from Galicia to the Valencian Community. The second axis begins in La Rioja and Navarra and extends to Catalonia. Finally, the third axis begins in western Andalusia and, crossing this autonomous community, extends to Murcia. 
Regarding the total number of places offered, the results shown in Table 4 indicate that, at the national level, the training offered by the food industry exceeds 12,300 places in 2018 . In addition, professional training exceeds university training in 1936 places, 7140 and 5204 places respectively. It additionally becomes visible that neither university training nor vocational training are homogeneously distributed throughout the territory; they differ from one province to another.

Table 4. Training offer in the food industry context by provinces, 2018.

\begin{tabular}{cccccccc}
\hline Province & $\begin{array}{c}\text { University } \\
\text { Training } \\
\text { Places }\end{array}$ & $\begin{array}{c}\text { Vocational } \\
\text { Training } \\
\text { Places }\end{array}$ & $\begin{array}{c}\text { Total } \\
\text { Places }\end{array}$ & Province & $\begin{array}{c}\text { University } \\
\text { Training } \\
\text { Places }\end{array}$ & $\begin{array}{c}\text { Vocational } \\
\text { Training } \\
\text { Places }\end{array}$ & $\begin{array}{c}\text { Total } \\
\text { Places }\end{array}$ \\
\hline Barcelona & 665 & 570 & 1235 & Jaén & 75 & 120 & 195 \\
Valencia & 689 & 330 & 1019 & Las Palmas & 0 & 180 & 180 \\
Madrid & 527 & 390 & 917 & Lugo & 95 & 60 & 155 \\
Alicante & 185 & 300 & 485 & Toledo & 0 & 150 & 150 \\
Lleida & 155 & 330 & 485 & Asturias & 18 & 120 & 138 \\
Murcia & 285 & 180 & 465 & Álava & 40 & 90 & 130 \\
Girona & 105 & 300 & 405 & Cantabria & 0 & 120 & 120 \\
La Rioja & 285 & 90 & 375 & Ourense & 0 & 120 & 120 \\
Pontevedra & 165 & 180 & 345 & Castellón & 0 & 90 & 90 \\
Córdoba & 120 & 210 & 330 & Huelva & 0 & 90 & 90 \\
Badajoz & 205 & 120 & 325 & Palencia & 0 & 90 & 90 \\
Zaragoza & 110 & 210 & 320 & Salamanca & 30 & 60 & 90 \\
Tarragona & 70 & 240 & 310 & Teruel & 0 & 90 & 90 \\
Bizkaia & 25 & 270 & 295 & Baleares & 15 & 60 & 75 \\
Ciudad Real & 110 & 180 & 290 & Soria & 72 & 0 & 72 \\
Coruña, A & 45 & 240 & 285 & Gipuzkoa & 0 & 60 & 60 \\
Cádiz & 155 & 120 & 275 & Huesca & 0 & 60 & 60 \\
Granada & 90 & 180 & 270 & Málaga & 0 & 60 & 60 \\
S. Tenerife & 20 & 240 & 260 & Zamora & 0 & 60 & 60 \\
Almería & 150 & 90 & 240 & Ceuta & 0 & 30 & 30 \\
Sevilla & 90 & 150 & 240 & Ávila & 20 & 0 & 20 \\
Valladolid & 143 & 90 & 233 & Cáceres & 15 & 0 & 15 \\
Albacete & 70 & 150 & 220 & Cuenca & 0 & 0 & 0 \\
Burgos & 160 & 60 & 220 & Guadalajara & 0 & 0 & 0 \\
León & 85 & 120 & 205 & Segovia & 0 & 0 & 0 \\
Navarra & 115 & 90 & 205 & Melilla & 0 & 5140 & 12,344 \\
\hline & & & & Total & 5204 & & 0 \\
\hline
\end{tabular}

Nevertheless, the number of places offered in a province will depend on its size effect. Seeking to solve this problem, the statistical analysis performed considers this issue relativizing the data according to the number of inhabitants in each province. As explained above, two kinds of provinces were distinguished in order to check whether differences exist-in terms of the training offered-between areas with industrial districts and those where this production model is absent in the food industry.

Table 5 shows the number of cases in each sample, the mean, the standard deviation, and the variation coefficient in each one of the variables (university training, vocational training, and overall training) for both groups. The results confirm not only the existence of differences in means in the overall training offer between provinces in which food industrial districts exist and those in which such districts are absent, but also that these differences are statistically significant $(p \leq 0.05)$. Hypothesis 2 , referred to the positive relationship between the productive specialization of a region and the training offer of such industry, can be deemed as verified.

However, if we analyze separately the different kinds of training, we get important differences. On the one hand, university training is clearly superior in the regions where there is productive specialization and these differences in means are statistically significant $(p \leq 0.008)$. This fact allows us to confirm Hypothesis 2a, which postulates the existence of a positive relationship between the productive specialization of a region and the university training oriented to the industry in which the region is specialized. On the other hand, vocational training does not show significant differences 
depending on the degree of productive specialization of the regions. However, we cannot consider Hypothesis $2 b$ valid, which assumes a positive relationship between the specialization of a region and the professional training offered. Based on the above, it should be noted that the differences in the training offer will be explained almost entirely by the university training offer, given that no significant differences have been detected in terms of vocational training.

Table 5. Comparison between provinces with/without districts and the training offer of the food industry.

\begin{tabular}{ccccccc}
\hline & \multicolumn{2}{c}{ University Training } & \multicolumn{2}{c}{ Vocational Training } & \multicolumn{2}{c}{ Overall Training } \\
\hline & $\begin{array}{c}\text { Provinces } \\
\text { with FIDs }\end{array}$ & $\begin{array}{c}\text { Provinces } \\
\text { without FIDs }\end{array}$ & $\begin{array}{c}\text { Provinces } \\
\text { with FIDs }\end{array}$ & $\begin{array}{c}\text { Provinces } \\
\text { without FIDs }\end{array}$ & $\begin{array}{c}\text { Provinces } \\
\text { with FIDs }\end{array}$ & $\begin{array}{c}\text { Provinces } \\
\text { without FIDs }\end{array}$ \\
\hline No. of cases & 21 & 31 & 21 & 31 & 21 & 31 \\
Mean & $0.207^{* * *}$ & 0.073 & 0.200 & 0.200 & $0.408^{* *}$ & 0.274 \\
(SD) & 0.235 & 0.110 & 0.163 & 0.159 & 0.303 & 0.189 \\
(VC) & 1.132 & 1.496 & 0.816 & 0.795 & 0.743 & 0.688 \\
\hline \multicolumn{7}{r}{$p \leq 0.05 ; * * * 0.01}$.
\end{tabular}

Several arguments can be used to explain the different results of $\mathrm{H} 2 \mathrm{a}$ and $\mathrm{H} 2 \mathrm{~b}$, but perhaps the most important is the one mentioned above concerning the homogeneity of professional training at the national level. The vocational training centers are distributed in a uniform way in the territory (with presence in practically all the provinces) and with a varied training offer, among other reasons to guarantee a diversified training that allows to strengthen the various economic sectors. In practice, this fact favors the development of a training base common to the entire national territory without considering the differences in the demand for training between the different regions.

\section{Conclusions}

This paper analyzed the link in terms of spatial distribution between the different food industrial districts and the institutions (technological centers, research institutes, universities, vocational training centers, entrepreneurs' associations, and interprofessional organizations) which give support to this industry nationwide, together with the function performed by institutions as knowledge generators.

As highlighted above, institutions play a key role in the economic success of regions (Amin and Thrift 1995) and are especially important in the case of industrial districts, where a productive specialization exists around a particular sector or industry. Such a productive specialization favors the concentration of institutions specific to the industry within a well-defined geographical area. Furthermore, a successive concentration of highly specialized techniques and knowledge takes place in the district which can be accessed by the group of firms located therein (Marco-Lajara et al. 2018). Hence, the focus of the hypotheses posed on verifying the proximity between industrial districts and institutions, as well as the role that the latter play as generators of knowledge for the enterprises located in the region.

Firstly, the results allowed us to check that a productive specialization exists not only inside industrial districts but also by regions in Spain, at least for the food industry. While several food industrial districts concentrate in some regions, this production model is less representative, and sometimes even non-existent, in others. Similarly, evidence has been provided which shows that the training offer in the food industry context is not homogenously distributed throughout the national territory; it changes from one region to another.

Secondly, the results confirm that the food industry support institutions are located close to the geographical context of food industrial districts. More precisely, at least six institutions which support this sector can be found in six of each seven provinces with food industrial districts. This verifies the theoretical postulates according to which a proximity relationship exists between district enterprises and the institutions which provide them with information and technical support, amongst other things. In any case, what matters most, is that this regional and local institutional support ultimately implies a boost to the competitiveness of the SMEs located there. 
Finally, we were able to check empirically that the training offer within the food industry context in those regions where food industrial districts exist exceeds that of regions in which such districts are absent. Specifically, in the regions where we find this production model, the training offer in the field of the food industry is, on average, 1.5 times higher than in the regions where this production model has not been identified. It is important to remark that the coefficient of overall training reaches a very high level in some provinces with food industrial districts (specially La Rioja and Lleida). In these regions the training offer is much higher than the national average. Therefore, this leads us to conclude that the productive specialization in a specific territory positively correlates with the training offered in the region, oriented to meeting the industry's training needs. The above statement is true at least within the food industry and when considering the province as the territorial unit of reference. Nevertheless, when we distinguish between university and vocational training the results are different. Whereas in the case of universities we can identify a significant and positive relationship between the productive specialization and training offer, it is not the same for vocational training centers. In this case, there is no relationship due to the high degree of homogeneity of the training offer in the territory.

Now that we are aware of the spatial distribution of the institutions which support the food industry at a national level and having checked that such distribution largely matches that of food industrial districts, the next step should be to study the relationship existing between these two fields: The institutional and the business one. Although institutional thickness necessarily requires the presence of institutions, that is not a sufficient condition; it actually entails the interaction synergies, the collective representation, and a common purpose of the agents involved as well (Keeble et al. 1999).

In that respect, we suggest analyzing the depth and quality of the relationships between the industry support institutions and the firms located in industrial districts as interesting lines of research for the future. Expressed differently, we suggest investigating aspects linked to social capital in the district context, and the role played by institutions in its development. Finally, it seems relevant for us to examine the influence exerted by that social capital on the performance of the firms which belong to this network of relationships.

Author Contributions: Conceptualization, P.S.-L. and B.M.-L.; methodology, L.R.-F.; software, E.S.-G.; validation, L.R.-F. and E.S.-G.; formal analysis, P.S.-L.; investigation, P.S.-L.; data curation, P.S.-L.; writing-original draft preparation P.S.-L.; writing-review and editing, E.C.-C. and B.M.-L.; supervision, E.C.-C. and B.M.-L.; project administration, E.C.-C.

Funding: This research received no external funding.

Conflicts of Interest: The authors declare no conflict of interest.

\section{References}

Amin, Ash, and Nigel Thrift. 1995. Globalization, Institutions, and Regional Development in Europe. Oxford: Oxford University Press.

Asheim, Bjørrn, Ron Boschma, and Philip Cooke. 2011. Constructing Regional Advantage: Platform Policies Based on Related Variety and Differentiated Knowledge Bases. Regional Studies 45: 893-904. [CrossRef]

Barney, Jay. 1991. Firm Resources and Sustained Competitive Advantage. Journal of Management 17: 99-120. [CrossRef]

Becattini, Giacomo. 2002. Del Distrito Industrial Marshalliano a La «Teoría Del Distrito» Contemporánea. Una Breve Reconstrucción Crítica. Investigaciones Regionales 1: 9-32.

Bell, Geoffrey G. 2005. Clusters, Networks, and Firm Innovativeness. Strategic Management Journal 26: $287-95$. [CrossRef]

Belso-Martínez, José Antonio, F. Xavier Molina-Morales, and Francisco Mas-Verdu. 2011. Clustering and Internal Resources: Moderation and Mediation Effects. Journal of Knowledge Management 15: 738-58. [CrossRef]

Belzunegui Eraso, Ángel, Miguel Ángel Miralles Amorós, and María Teresa Pastor Gonsálbez. 2017. The Role of Institutional and Territorial Factors in Innovation: The Case of the Spanish Footwear Components Industry. Investigaciones Regionales-Journal of Regional Research 39: 59-80. 
Boix, Rafael, and Vittorio Galletto. 2006. El Nuevo Mapa de los Distritos Industriales de España y su Comparación con Italia y el Reino Unido. Working Papers 06.04. Barcelona: Department of Applied Economics at Universitat Autonoma of Barcelona.

Boix, Domenech Rafel, and Joan Trullén. 2011. La relevancia empírica de los distritos industriales marshallianos y los sistemas productivos locales manufactureros de gran empresa en España. Investigaciones Regionales 19: 75-96.

Boucher, Gerry, Cheryl Conway, and Els Van Der Meer. 2003. Tiers of Engagement by Universities in Their Region's Development. Regional Studies 37: 887-97. [CrossRef]

Bullinger, Hans-Jorg, Karin Auernhammer, and Axel Gomeringer. 2004. Managing Innovation Networks in the Knowledge-Driven Economy. International Journal of Production Research 42: 3337-53. [CrossRef]

Camisón, César, and Xavier Molina-Morales. 1998. El Distrito Industrial Cerámico Valenciano: ¿Mito o Realidad Competitiva? Revista Valenciana d'Estudis Autonòmics 83-102.

Charles, David, Sally Hayward, and Damien Thomas. 1995. Science Parks and Regional Technology Strategies. Industry and Higher Education 9: 332-39. [CrossRef]

Comeche Martínez, Jose M., Ana Debón Aucejo, and Francisco Puig Blanco. 2006. La Localización Industrial como Elemento de Cooperación en los Emprendedores. El Caso Particular del Emprendedor Internacional. In La Formación de Emprendedores como Clave para el Desarrollo. Edited by Francisco Morea and Mariel Fornoni. Mar del Plata: Suárez, pp. 51-76.

Dalziel, Margaret. 2006. The Impact of Industry Associations: Evidence from Statistics Canada Data. Innovation 8: 296-306. [CrossRef]

Díaz-Díaz, Nieves L., and Petra de Saá Pérez. 2014. The Interaction between External and Internal Knowledge Sources: An Open Innovation View. Journal of Knowledge Management 18: 430-46. [CrossRef]

Drejer, Ina, and Birte Holst Jørgensen. 2005. The Dynamic Creation of Knowledge: Analysing Public-Private Collaborations. Technovation 25: 83-94. [CrossRef]

Dyer, Jeffrey H., and Harbir Singh. 1998. The Relational View: Cooperative Strategy and Sources of Interorganizational Competitive Advantage. Academy of Management Review 23: 660-79. [CrossRef]

Feldman, Maryann P., and Nadine Massard, eds. 2002. Location, Location, Location: Institutions and Systems in the Geography of Innovation. In Institutions and Systems in the Geography of Innovation. Boston: Springer, pp. 1-20.

FIAB. 2017. Available online: http:/ / fiab.es/es/archivos/documentos/INFORME_ECONOMICO_FIAB_2017.pdf (accessed on 28 January 2019).

Gallaud, Delphine, and André Torre. 2004. Geographical Proximity and Circulation of Knowledge through Inter-Firm Cooperation. In Academia-Business Links. Edited by Rüdiger Wink. London: Palgrave Macmillan, pp. 137-58. [CrossRef]

Gertler, Meric S. 2003. Tacit Knowledge and the Economic Geography of Context, or the Undefinable Tacitness of Being (There). Journal of Economic Geography 3: 75-99. [CrossRef]

Grant, Robert M. 1991. The Resource-Based Theory of Competitive Advantage: Implications for Strategy Formulation. California Management Review 33: 114-35. [CrossRef]

Keeble, David, Clive Lawson, Barry Moore, and Frank Wilkinson. 1999. Collective Learning Processes, Networking and 'Institutional Thickness' in the Cambridge Region. Regional Studies 33: 319-32. [CrossRef]

Kirat, Thierry, and Yannick Lung. 1999. Innovation and Proximity. European Urban and Regional Studies 6: 27-38. [CrossRef]

Knudsen, Mette Praest. 2007. The Relative Importance of Interfirm Relationships and Knowledge Transfer for New Product Development Success. Journal of Product Innovation Management 24: 117-38. [CrossRef]

Lane, Peter J., and Michael Lubatkin. 1998. Relative Absorptive Capacity and Interorganizational Learning. Strategic Management Journal 19: 461-77. [CrossRef]

Lev, Baruch, and Juergen H. Daum. 2004. The Dominance of Intangible Assets: Consequences for Enterprise Management and Corporate Reporting. Measuring Business Excellence 8: 6-17. [CrossRef]

López-Estornell, Manuel, José-Vicente Tomás-Miquel, and Manuel Expósito-Langa. 2015. Conocimiento y Efecto Distrito en las Empresas Innovadoras. Un Estudio en la Región Valenciana. Revista de Estudios Regionales 101: 189-216.

Maggioni, Mario A., Mario Nosvelli, and Teodora Erika Uberti. 2007. Space versus Networks in the Geography of Innovation: A European Analysis. Papers in Regional Science 86: 471-93. [CrossRef] 
Marco-Lajara, Bartolomé, Patrocinio Carmen Zaragoza-Sáez, Enrique Claver-Cortés, and Mercedes Úbeda-García. 2017. Does institutional knowledge attract new firms in tourist districts? Tourism Economics 23: 898-910. [CrossRef]

Marco-Lajara, Bartolomé, Patrocinio Zaragoza-Sáez, Enrique Claver-Cortés, and Mercedes Úbeda-García. 2018. Hotel Performance and Knowledge Sources in Spanish Tourism Districts. Current Issues in Tourism 21: 1988-2013. [CrossRef]

Marshall, Alfred. 1920. Principles of Economics. London: Macmillan.

McCann, Brian T., and Timothy B. Folta. 2011. Performance Differentials within Geographic Clusters. Journal of Business Venturing 26: 104-23. [CrossRef]

Oakey, Ray P. 1995. High-Technology Small Firms: Variable Barriers to Growth. London: Paul Chapman, ISBN 1853962392.

Parra-Requena, Gloria, Pedro García-Villaverde, and Juan José Jiménez-Moreno. 2008. Coopetición y Ventaja Competitiva en los Distritos Industriales. Investigaciones Europeas de Dirección y Economía de La Empresa 14: 85-102. [CrossRef]

Parra-Requena, Gloria, María J. Ruiz-Ortega, and Pedro Garcia-Villaverde. 2013. Social Capital and Effective Innovation in Industrial Districts: Dual Effect of Absorptive Capacity. Industry and Innovation 20: 157-79. [CrossRef]

Peng, Roger. 2015. The Reproducibility Crisis in Science: A Statistical Counterattack. Significance 12: 30-32. [CrossRef]

Porter, Michael E., and Christian Ketels. 2009. Clusters and Industrial Districts: Common Roots, Different Perspectives. In A Handbook of Industrial Districts. Edited by Giacomo Becattini, Marco Bellandi and Lisa De Propris. Cheltenham: Edward Elgar Publisher, pp. 172-83. ISBN 978-1-847202673.

Razak, Azley Abd, and Mohammed Saad. 2007. The Role of Universities in the Evolution of the Triple Helix Culture of Innovation Network: The Case of Malaysia. International Journal of Technology Management and Sustainable Development 6: 211-25. [CrossRef]

Rodríguez-Cohard, Juan Carlos, and Manuel Parras. 2011. The Olive Growing Agri-Industrial District of Jaén and the International Olive Oils Cluster. Open Geography Journal 4: 55-72. [CrossRef]

Torre, Andre, and Alain Rallet. 2005. Proximity and Localization. Regional Studies 39: 47-59. [CrossRef]

(C) 2019 by the authors. Licensee MDPI, Basel, Switzerland. This article is an open access article distributed under the terms and conditions of the Creative Commons Attribution (CC BY) license (http:/ / creativecommons.org/licenses/by/4.0/). 